\title{
THE ROLE OF GREEN TEA IN ORAL HEALTH - A REVIEW
}

\author{
MEENAKSHI MOHAN*, GANESH JEEVANANDAN, MITHUN RAJA S
}

Department of Pediatric and Preventive Dentistry, Saveetha Dental College, Saveetha University, Chennai, Tamil Nadu, India. Email: Drmeena.mohan23@gmail.com

Received: 13 November 2017, Revised and Accepted: 15 December 2017

\begin{abstract}
Tea is the most widely consumed and a popular beverage in the world. Over the past decade, molecular components of teas and their health benefits on humans have received increasing attention from researchers. Functional foods are foods with positive health benefits that extend beyond their normal nutritional value. They interrupt the functions of the body and help in the management of specific health conditions and preventing pathologic changes. One such nature's gift is green tea. Green tea, a leading beverage in the Far East for the past thousand years, is an important source of polyphenol antioxidants. (EGCG) epigallocatechin 3 gallate, a polyphenol, constitute the most interesting components in green tea leaves. There is an increasing interest on the health benefits of green tea in the field of oral health. Green tea is renowned for its antioxidant, anti-cariogenic, anti inflammatory and antimicrobial properties. This traditional beverage is also used in the management of chronic systemic diseases including carcinoma. Recent studies has emphasized that in addition to the microbial activity, the host immuno-inflammatory reactions destroy the oral tissues to a greater extent. In such cases green tea is considered to be a natural preventive and curative agent. There is a growing search of evidence for understanding the beneficial role of green tea and its polyphenols in oral health. Numerous studies have shown the beneficial effects on the regular intake of green tea in maintaining oral health. Even though studies demonstrate the health effects of green tea polyphenols, more clinical and biological studies to support guidelines for green tea intake as part of prevention and treatment of specific oral pathologies are needed.
\end{abstract}

Keywords: Antioxidant, Green tea, Oral health, Polyphenols.

(C) 2018 The Authors. Published by Innovare Academic Sciences Pvt Ltd. This is an open access article under the CC BY license (http://creativecommons. org/licenses/by/4. 0/) DOI: http://dx.doi.org/10.22159/ajpcr.2018.v11i4.23628

\section{INTRODUCTION}

Green tea, an unoxidized tea, is derived from Camellia sinensis. Green tea is obtained from $C$. sinensis by undergoing minimal oxidation during the process [1]. Green tea first originated in China and it was first cultivated in $2737 \mathrm{BC}$ during the period of Emperor Chen Nung. It is serving as a beverage as well as a medicine over the years. Green tea has been subjected to numerous scientific and medical studies to determine the extent of its health benefits in recent years [2]. There are three varieties of tea, namely, green tea, black tea, and oolong. All the three varieties are derived from $C$. sinensis plant, while the difference between them is the method of processing [3]. Green tea is unfermented (produced by drying and steaming the leaves to inactivate the polyphenol oxidase, thus no oxidation occurs), oolong is semi-fermented (produced when the leaves are subjected to partial fermentation before drying), and black tea is fully fermented (a post-harvest fermentation stage before drying and steaming). Since fermenting results in a loss of various essential components, green tea remains as the richest source of antioxidants (Table 1), explicitly polyphenols [4]. Hence, this review article elaborates on the various beneficial effects of green tea on oral health.

\section{EFFECT OF GREEN TEA ON ORAL HEALTH}

Green tea and dental caries

Dental enamel is comprised of hydroxyapatite crystals. The solubility of hydroxyapatite rises with the decrease in $\mathrm{pH}$ which is harmful to the tooth enamel [7]. The EGCG extract from the green tea causes a reduction in acid production and maintains $\mathrm{pH}$ by inhibiting the enzyme lactate dehydrogenase which is responsible for producing lactic acid from pyruvate [8]. Preventing the adhesion of bacteria to the glycoprotein layer is an additional mechanism explaining the anticariogenicity. A study has concluded that rinsing the mouth for 1 week with green tea mouthwash significantly reduces the salivary levels of Streptococcus mutans and Lactobacillus [3]. Reports have proved that green tea decreases the susceptibility of dental caries in both humans and animals [2]. Frequent intake of green tea can significantly decrease caries formation, even in the presence of sugar in the diet [9]. Green tea extract also reduces a-amylase activity in saliva which makes it act as an anticariogenic agent $[10,11]$.

\section{Green tea and halitosis}

Halitosis, due to dental caries and poor oral hygiene, is attributable mainly due to volatile sulfur compounds. Few breath refreshing chewing gums and mouth spray contain polyphenols, which are a major ingredient of green tea [12]. A study has reported that using green tea mouthwash significantly reduces the volatile sulfur components level in patients with gingivitis [13]. Another study has demonstrated that green tea extract had the ability to remove odorant sulfur [14].

\section{Green tea and antiviral property}

Polyphenols which act as antioxidant inhibit the enzymes that damage the cell membrane and prevent penetration of the virus into the cells [15]. This property of green tea is quite essential as it can prevent the oral viral diseases. EGCG is said to have ability to prevent infection from influenza virus by attaching to viral hemagglutinin, thus preventing its attachment to cellular target receptors [16]. A study revealed that EGCG, EGC, and ECG were found potent to inhibit influenza virus by hemagglutination inhibition. EGCG and ECG suppress the viral RNA synthesis, while EGC fails to exhibit this property [17]. Green tea is also stated to have its effect against human immunodeficiency virus type 1, herpes simplex virus, Epstein-Barr virus, and adenoviruses [15].

\section{Green tea and antifungal property}

Candida albicans, a part of the indigenous microbial flora in humans, is unique among opportunistic pathogens because it is a part of the normal microbial flora of the host [18]. Candidiasis is a most common outbreak of $C$. albicans in the oral cavity. Amphotericin B (polyene antibiotics) and fluconazole (azole antifungal agent) have the strongest antifungal activity, especially against $C$. albicans. Antimycotic-resistant isolates of C. albicans have appeared which act a major drawback [19]. Hence, a crude substitute was considered necessary. A study showed synergic 
Table 1: Composition of green tea [1,4-6]

\begin{tabular}{lll}
\hline Macronutrients & Micronutrients & Organic substance \\
\hline $\begin{array}{l}\text { Protein such as } \\
\text { enzymes- 15-20\% of dry weight }\end{array}$ & Vitamins B, C, E. & $\begin{array}{l}\text { Most important component of green tea is } \\
\text { polyphenols }\end{array}$ \\
$\begin{array}{l}\text { Carbohydrates: Cellulose, pectin, } \\
\text { glucose, fructose, and sucros }\end{array}$ & and carotenoids & Polyphenols of green tea are catechins (flavan-3-ols). \\
e-1-7\% of dry weight & Volatile components - aldehydes & The four main catechins are: \\
Lipid components: Linoleic and & Minerals and trace elements- Ca, & (EGCG) Epigallocatechin-3-gallate-59\% \\
linolenic acids & $\mathrm{Mg}, \mathrm{Mn}, \mathrm{Cr}, \mathrm{Fe}, \mathrm{Al}, \mathrm{F}, \mathrm{K}, \mathrm{Cu}, \mathrm{Zn}, \mathrm{Mo}, \mathrm{Se}$, & (EGC) Epicatechin three gallate-13.6\% \\
Sterols such as stigmasterol & $\mathrm{Na}, \mathrm{P}, \mathrm{Co}, \mathrm{Sr}, \mathrm{Ni}$ & (EC) Epicatechin-6.4\%
\end{tabular}

antifungal activity when a combination of EGC and antimycotics was used against $C$. albicans. It also concluded that the combined use of EGC and low dosage of amphotericin-B inhibited the growth of $C$. albicans, and the action was proved to be fungicidal [20].

\section{Green tea and periodontitis}

Gingival sulcus, which harbors numerous microorganisms (mainly anaerobes), deepens forming a periodontal pocket in cases of periodontitis. In periodontitis, local infiltration of polymorphs and serum exudates takes place. Anaerobic black-pigmented bacteria such as Prevotella sp. and Porphyromonas digitalis are commonly associated with periodontal disease [21]. In vitro studies showed that green tea catechin inhibits the growth of Porphyromonas gingivalis, Prevotella intermedia, and Prevotella nigrescens, by inhibiting the adherence of $P$. gingivalis onto human buccal epithelial cells and also by inhibiting the production of toxic metabolites of $P$. gingivalis [22]. Green tea polyphenol also increases osteoblastogenesis and suppresses osteoclastogenesis, thus preventing the bone from destruction and preserving the periodontium [23]. Green tea catechin given by local delivery system using hydroxypropyl cellulose strips is said to inhibit the growth of bacteria. Continuous application of green tea catechin was reported as an effective method for improvement of periodontitis [24]. EGCG, with its ability to inhibit the formation of osteoclasts and induce apoptosis cell death of osteoclasts, is also considered for improving periodontal health [25]. Green tea is also recognized for their roles in host defense, human gingival cells, and inflammatory response [26,27].

\section{Green tea and oral malignancy}

Oral squamous cell carcinoma, a most common head and neck malignancy, is characterized by high rates of morbidity and mortality [28]. Hamsters with induced buccal pouch tumor were given green tea till the end of the experiment. It was noticed that hamsters of the study group when compared with the control group showed lesser pathological changes and tumor size [29,30]. Studies have been conducted to show that green tea polyphenols may induce apoptosis and delay in the cell cycle in tumor cells while not disturbing the normal cells [31]. Another study showed that tongue carcinoma culture supplemented with EGCG causes inhibition of cell invasion. This was furthermore confirmed by administering EGCG in SCC-induced mice, which showed dose-dependent tumor growth inhibition and reduced hepatocyte growth factor expression [32].

\section{Over consumption of green tea}

Over consumption of green tea is least likely to disrupt sleep quality at night. Pregnant and breastfeeding women should drink no more than 1-2 cups/day, as it can cause an increased heart rhythm. It is also important to control the consumption of green tea in renal disorders, due to its diuretic effects [4]. Aluminum present in green tea, as revealed by few studies, has a high capacity to cause neurological diseases [34]. Over intake of green tea catechins decreases the iron bioavailability from the diet. In vivo study has proved that green tea polyphenols can cause oxidative stress and liver toxicity at certain concentrations. Patients on Warfarin are contraindicated to take green tea as green tea contains Vitamin K. Green tea should also not be taken with aspirin because it prevents platelets from clotting [34].
Other health benefits

Apart from oral health, review of literature shows various general health befits of consuming green tea $[3,35]$. Some of them includes: Anti-inflammatory activity, antimicrobial activity, antidiabetic activity [36,37], anti-obesity effect [36], antihypertensive effect, cardiac effects, blood pressure control, gastro and hepatoprotective effect, and neuroprotective effect $[33,37,38]$.

\section{CONCLUSION}

Drinking green tea is a healthy habit to maintain a healthy life. Various studies have demonstrated that green tea possesses antioxidant, antimutagenic, antidiabetic, anti-inflammatory, antibacterial, and antiviral, and above all, cancer-preventive properties. Yet it is not entirely clear whether green tea potency is because of its phenolic ingredients or other nutritional components. More research is needed to advocate the beneficial mechanisms of green tea. Review of the literature concluded that green tea taken as a daily supplement can improve the health status. Hence, it is considered to be a wholesome drink for a healthy living.

\section{AUTHORS CONTRIBUTION}

Concept and collection of data - Meenakshi Mohan, Ganesh Jeevanandan. Writing the article and critical review of article - Meenakshi Mohan, Mithunraja. Final approval of the article - Ganesh Jeevanadan.

\section{CONFLICT OF INTEREST}

Nil.

\section{REFERENCES}

1. Ramadon D, Pramesti SS, Anwar E. Formulation, stability test and in vitro penetration study of transethosomal gel containing green tea (Camellia sinensis L. Kuntze) leaves extract. Int J Appl Pharm 2017;9:91-6.

2. Wu CD, Wei GX. Tea as a functional food for oral health. Nutrition 2002;18:443-4.

3. Cabera C, Artacho R, Gimenez R. Beneficial effects of green tea-A review. J Am Coll Nutr 2006;25:79-99.

4. McKay DL, Blumberg JB. The role of tea in human health: An update. J Am Coll Nutr 2002;21:1-3.

5. Ferrazzano GF, Roberto L, Amato I, Cantile T, Sangianantoni G, Ingenito A. Antimicrobial properties of green tea extract against cariogenic microflora: An in vivo study. J Med Food 2011;14:907-11.

6. Lin YS, Tsai YJ, Tsay JS, Lin JK. Factors affecting the levels of tea polyphenols and caffeine in tea leaves. J Agric Food Chem 2003;51:1864-73.

7. Dawes $\mathrm{C}$. What is the critical $\mathrm{pH}$ and why does a tooth dissolve in acid? J Can Dent Assoc 2003;69:722-4.

8. Hirasawa M, Takada K, Otake S. Inhibition of acid production in dental plaque bacteria by green tea catechins. Caries Res 2006;40:265-70.

9. Linke HA, LeGeros RZ. Black tea extract and dental caries formation in hamsters. Int J Food Sci Nutr 2003;54:89-95.

10. Zhang J, Kashket S. Inhibition of salivary amylase by black and green teas and their effects on the intraoral hydrolysis of starch. Caries Res 1998;32:233-8.

11. Hirao K, Yumoto H, Nakanishi T, Mukai K, Takahashi K, Takegawa D, et al. Tea catechins reduce inflammatory reactions via mitogen-activated 
protein kinase pathways in toll-like receptor 2 ligand-stimulated dental pulp cells. Life Sci 2010;86:654-60.

12. Zeng QC, Wu AZ, Pika J. The effect of green tea extract on the removal of sulfur-containing oral malodor volatiles in vitro and its potential application in chewing gum. J Breath Res 2010;4:036005.

13. Rassameemasmaung S, Phusudsawang P, Sangalungkarn V. Effect of green tea mouthwash on oral malodor. ISRN Prev Med 2013;2013:975148.

14. Lodhia P, Yaegaki K, Khakbaznejad A, Imai T, Sato T, Tanaka T, et al. Effect of green tea on volatile sulfur compounds in mouth air. J Nutr Sci Vitaminol (Tokyo) 2008;54:89-94

15. Friedman M. Overview of antibacterial, antitoxin, antiviral, and antifungal activities of tea flavonoids and teas. Mol Nutr Food Res 2007;51:116-34.

16. Nakayama M, Suzuki K, Toda M, Okubo S, Hara Y, Shimamura T, et al. Inhibition of the infectivity of influenza virus by tea polyphenols. Antiviral Res 1993;21:289-99.

17. Song JM, Lee KH, Seong BL. Antiviral effect of catechins in green tea on influenza virus. Antiviral Res 2005;68:66-74.

18. Shepherd MG. The pathogenesis and host defence mechanisms of oral candidosis. N Z Dent J 1986;82:78-81.

19. Pfaller MA, Diekema DJ, Jones RN, Messer SA, Hollis RJ, SENTRY Participants Group. et al. Trends in antifungal susceptibility of Candida spp. Isolated from pediatric and adult patients with bloodstream infections: SENTRY antimicrobial surveillance program, 1997 to 2000. J Clin Microbiol 2002;40:852-6.

20. Hirasawa M, Takada K. Multiple effects of green tea catechin on the antifungal activity of antimycotics against Candida albicans. J Antimicrob Chemother 2004;53:225-9.

21. Chapple IL. Reactive oxygen species and antioxidants in inflammatory diseases. J Clin Periodontol 1997;24:287-96.

22. Kushiyama M, Shimazaki Y, Murakami M, Yamashita Y. Relationship between intake of green tea and periodontal disease. J Periodontol 2009;80:372-7.

23. Shen CL, Chyu MC, Wang JS. Tea and bone health: Steps forward in translational nutrition. Am J Clin Nutr 2013;98:1694S-9S.

24. Hirasawa M, Takada K, Makimura M, Otake S. Improvement of periodontal status by green tea catechin using a local delivery system: A clinical pilot study. J Periodontal Res 2002;37:433-8.

25. Yun JH, Pang EK. Inhibiting effects of green tea polyphenol epigallocatechin gallate on the expression of MMP-9 and on the formation of osteoclasts. J Periodont Res 2004;39:300-7.

26. Yang F, Oz HS, Barve S, De Villiers WJ, McClain CJ, Varilek GW. The green tea polyphenol (-)-epigallocatechin-3-gallate blocks nuclear factor- $\kappa \mathrm{B}$ activation by inhibiting I $\mathrm{KB}$ kinase activity in the intestinal epithelial cell line IEC-6. Mol Pharmacol 2001;60:528-33.

27. Priya M, Ramamurthy J. Effects of green tea in the treatment of periodontal disease. J Pharm Res Clin Pract 2014;4:79-83.

28. Lippman SM, Hong WK. Molecular markers of the risk of oral cancer. N Engl J Med 2001;344:1323-6.

29. Li N, Han C, Chen J. Tea preparations protect against DMBA-induced oral carcinogenesis in hamsters. Nutr Cancer 1999;35:73-9.

30. Li N, Chen X, Liao J, Yang G, Wang S, Josephson Y, et al. Inhibition of 7,12-dimethylbenz[a] anthracene (DMBA)-induced oral carcinogenesis in hamsters by tea and curcumin. Carcinogenesis 2002;23:1307-13.

31. Chen D, Milacic V, Chen MS, Wan SB, Lam WH, Huo C, et al. Tea polyphenols, their biological effects and potential molecular targets. Histol Histopathol 2008;23:487-96.

32. Chen PN, Chu SC, Kuo WH, Chou MY, Lin JK, Hsieh YS. Epigallocatechin-3 gallate inhibits invasion, epithelial-mesenchymal transition, and tumor growth in oral cancer cells. J Agric Food Chem 2011;59:3836-44.

33. Xu J, Zhu SG, Yang FM, Cheg LC, Hu Y, Pan GX, et al. The influence of selenium on the antioxidant activity of green tea. J Sci Food Agric 2003;83:451-5.

34. Hamdaoui $\mathrm{MH}$, Chabchob S, Heidhili A. Iron bioavailability and weight gains to iron-deficient rats fed a commonly consumed Tunisian meal "bean seeds ragout" with or without beef and with green or black tea decoction. J Trace Elem Med Biol 2003;17:159-64.

35. Rahmani AH, Aldebasi YH, Aly SM. Role of green tea and its constituent epigallocatechin-3-gallate in the health management. Int $\mathrm{J}$ Pharm Pharm Sci 2015;7:6-12.

36. Lim SM, Loh SP. In vitro antioxidant capacities and antidiabetic properties of phenolic extracts from selected citrus peels. Int Food Res J 2016;23:211-9.

37. Widyawati PS, Werdani YD, Setiokusumo C, Kartikasari A. In vitro antioxidant capacities and antidiabetic properties of Pluchea leaves and green tea mixtures at various proportions. Int J Pharm Pharm Sci 2017;9:203-8.

38. Baskar S. Role of green tea in dental problems. Int J Pharm Sci Rev Res 2015;33:73-5. 